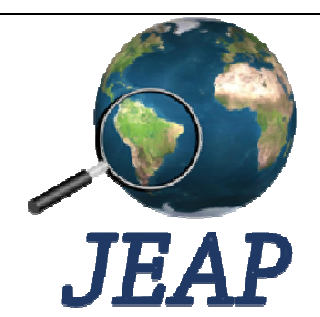

ISSN: 2525-815X

\section{Journal of Environmental} Analysis and Progress

Journal homepage: www.ufrpe.br/jeap

http://dx.doi.org/10.24221/jeap.2.1.2017.1023.23-35

\title{
Influence of functional traits on the demographic rates of 47 arboreal species in a tropical forest in northeastern Brazil
}

Hian de Assis Monteiro ${ }^{\mathrm{a}}$, André Luiz Alves de Lima ${ }^{\mathrm{b}}$, Ana Carolina Borges Lins-e-Silva ${ }^{\mathrm{a}}$, Maria Amanda Menezes Silva ${ }^{\mathrm{c}}$, Maria Jesus Nogueira Rodal ${ }^{\mathrm{a}}$

${ }^{a}$ Universidade Federal Rural de Pernambuco-UFRPE, Departmento de Biologia, Av. Dom Manoel de Medeiros, s/n, Dois Irmãos, Recife, PE, Brasil. CEP: 52.171-900. E-mail: mrodal@ terra.com.br.

${ }^{\mathrm{b}}$ UFRPE, Unidade Acadêmica de Serra Talhada-UAST, Serra Talhada, PE, Brasil. Caixa Postal 063. CEP: 56.909-535.

c Instituto Federal de Educação, Ciência e Tecnologia do Ceará-IFCE, Av. José de Freitas Queiroz, n. 5000, Cedro, Quixadá-CE, Brasil. CEP: 63.000-900.

\section{A R T I C L E I N F O}

Recebido 26 Oct 2016

Aceito 26 Dec 2016

Publicado 31 Jan 2017

\begin{abstract}
A B S T R A C T
Influence of functional traits on the demographic rates of 47 arboreal species in a tropical forest in northeastern Brazil. Based on the premise that species use different strategies for acquiring and maintaining resources, it is possible to identify similarities as determined by particular trade-offs between traits, the present work examined the specific leaf area (SLA), basic wood density (BWD), maximum height (Hmax) and seed shape (SS) of 47 arboreal species in an moist semievergreen tropical forest in northeastern Brazil and investigated the influence of those traits on plant mortality rates (MR) and growth (BAG). BWD and Hmax were the best predictors of mortality rates. Factorial analysis explained $70.4 \%$ of the total variability, distributed among three factors composed of traits and rates. MR and Hmax were found to be more readily observed when orthogonally rotated by the varimax method, with the first factor explaining $26.9 \%$ of the variance. Cluster analyses and principal component analyses, whose matrices contained the variables MR, BAG, SLA, and Hmax for each species, confirmed the discriminant analysis and allowed the identification of four functional groups. The fact that some of the correlations encountered differed from previously published results (such as the negative relationship between maximum height and mortality) may reflect regional climatic seasonality or indicate that this strategy benefits plant species that reach the upper canopy and thus become well-established.

Keywords: Atlantic Forest, mortality, plant strategies, recruitment.
\end{abstract}

\section{Introduction}

In tropical environments, impacts of fragmentation have been intensively studied (Melo et al., 2013), investigations concerning the functional traits (Wright et al., 2007) and conflicting demands of plant performances (growth/survival and survival/ reproduction) have been undertaken in recent years with the objective of elaborating functional conservation plans, especially for arboreal species (Kitajima, 1994). The ability to identify and correlate functional characteristics with plant successes represents a useful tool for determining and evaluating ecological strategies (Wright et al., 2010).
In a perspective of achieving an understanding of which functional traits influence the plant species success - principally survival, growth, and reproduction - Ackerly (2003) noted the importance of research focusing on understanding variation in its vital traits. A number of traits have been proposed as basic to plant strategies and their success (Diaz et al., 2004), including basic wood density (BWD), which directly influences plant longevity, their relative rate growth, resistance to damage, and carbon storage (Chave et al., 2006); maximum height (Hmax), which is related to competition for light, fecundity, and regeneration time (Cornelissen et al., 2003); seed shape (SS), which 
is associated with seed viability duration, seed persistence in the soil, initial growth and establishment, and the capacity for plant dispersal and colonization (Thompson et al., 1993); and specific leaf area (SLA), which is related to relative growth rate, maximum photosynthetic rates, and investments in structural defenses (Reich et al., 1999).

These parameters, when compared to demographic rates, specifically mortality rates (MR) and basal area growth rates (BAG), demonstrate important variation and clear correlations (Poorter et al., 2008). Interpretations of these correlations allow us to speculate about physiological and anatomical aspects (Sack \& Frole, 2006) and growth-form strategies (Diaz et al., 2004). These traits are relatively easy to measure and can be obtained from large numbers of species (Westoby, 1998; Weiher et al., 1999; Cornelissen et al., 2003), and could provide predictions of ecosystem structural alterations in response to global climate change (Diaz et al., 2007).

Considering the influences of the traits mentioned above on species performances in ecosystems it should be possible to classify those species according to their strategies for resource acquisition, use, and maintenance (Lavorel et al., 1997). Some species show traits related to slow resource use and maximum maintenance (high construction costs), while others demonstrate both rapid resource acquisition and use (low construction costs) (Westoby \& Wright, 2006).

In tropical forests, for example, shade tolerant species usually show slow resource utilization patterns (demonstrating high BWD, low SLA, and producing large, non-spherical seeds) - and slower growth and mortality rates (Westoby et al., 2002; Chave et al., 2009; Poorter et al., 2010). The opposite behavior is observed among species that require high light intensities and use their available resources rapidly (with low BWD, high SLA, and producing small, spherical seeds) to invest in rapid growth - therefore being good colonizers of disturbed habitats (Reich et al., 2003; Wright et al., 2010). Despite recent increases in characteristic-based ecological studies, Chaturvedi et al. (2011) noted that there had been very few studies of water-limited tropical forests, such as the moist semi-evergreen tropical coastal forests in the northern region of northeastern Brazil (with a six-month dry period) (Schessel et al., 2008). Poorter et al. (2008), for example, examined a moist semi-evergreen tropical forest in Bolivia (with a seven-month dry period) and found that the morphological explained $54 \%$ of the variation in mortality rates.
Considering that most studies undertaken in tropical forests have demonstrated fundamentally conflicting demands reflecting different ecological strategies, it was expected that the plants growing in this tropical forest in northeastern Brazil would: 1) demonstrate high wood densities, low specific leaf areas, and low growth and mortality rates; as well as 2) produce round seeds capable of sustaining high growth rates.

\section{Material and Methods \\ Study area}

The present work was undertaken in the Mata de Zambana Forest $\left(7^{\circ} 42^{\prime} 47^{\prime \prime} S\right.$ x $\left.34^{\circ} 59^{\prime} 26^{\prime \prime} \mathrm{W}\right)$, a 387.8 ha forest fragment within the Usina São José/Group Cavalcanti Petribú USJ sugarcane plantation, on the northern coast of Pernambuco State, Brazil. This sugar plantation was established within the coastal forest domain and includes 106 remnant areas of mature forest surrounded by sugar cane fields; $40.4 \%$ of these forest fragments are smaller than 10 ha (Trindade et al., 2008). The regional climate is hot and humid, with dry summers. Lima et al. (2008) reported that approximately $20 \%$ of the trees in another forest situated less than $3 \mathrm{~km}$ from the Mata de Zambana study site lost their leaves during the dry season. The mean average annual temperature there is $24.9^{\circ} \mathrm{C}$; the average annual rainfall is $1687,88 \mathrm{~mm}$, distributed within a rainy season that extends from March to August, where $85 \%$ of annual precipitation occurring during the six-month rainy season and high interannual rainfall variability (Schessel et al., 2008). The landscape is dominated by low mountains composed of sedimentary formations from the Tertiary Period (over crystalline basement rocks) with slopes greater than 30\% (CPRH, 2003).

\section{Sampling}

Lins-e-Silva (2010) undertook the first survey of the Mata de Zambana forest fragment during the first semester of 2005 when were installed 30 plots of $10 \times 10 \mathrm{~m}$. All of the live woody individuals in all of the plots with stem circumferences measured at $1.3 \mathrm{~m}$ above ground level $(\mathrm{CBH})>15 \mathrm{~cm}$ (hereafter-called canopy plants) were measured and labeled. 30 sub-plots $(5 \times 5 \mathrm{~m})$ were established within the larger plots in which all of the woody individuals with $\mathrm{CBH}<$ $15 \mathrm{~cm}$ but trunk circumferences at soil level $>3$ $\mathrm{cm}$ were measured and labeled (hereafter called the Woody sub-canopy). The repeat census was undertaken during the first semester of 2011. 


\section{Characteristics and demographic rates}

The following traits were estimated in 2011: specific leaf area (SLA); basic wood density (BWD); maximum height (Hmax), and seed shape (SS). SLA was determined following Cornelissen et al. (2003), in which 20 leaves per species were collected (a maximum of five per individual). As leaf area can vary during the day, the collections were made only in the first two or three hours after sunrise. The leaf samples were wrapped in wet sheet, sealed in plastic sacks, and subsequently cooled. The leaves were scanned and their areas calculated using Image-Pro Plus 4.5 software (demonstration license). The leaf material was then dried at $60^{\circ} \mathrm{C}$ for $72 \mathrm{~h}$ and its dry mass determined. SLA values are obtained by dividing the leaf areas by their corresponding dry masses.

Calculations of BWD involved collecting five stem samples approximately $10 \mathrm{~cm}$ long from five different individuals per species (Cornelissen et al., 2003). The core samples were removed from healthy individuals at $1.3 \mathrm{~m}$ above soil level using a Pressler borer. Water immersion made a measure of basic wood density.

The maximum tree height (Hmax) was estimated considering healthy adult plants whose canopies were totally exposed to sunlight, excluding trees that were only partially exposed to full sunlight. As this parameter is quite variable under natural conditions, Hmax values were derived from the measurements of the 10 tallest trees sampled. Height was considered the distance between the major photosynthetic tissues in the crowns of the trees to soil level (Cornelissen et al., 2003).

Seed shape (SS) was measured using calipers and estimated following Thompson et al. (1993) by calculating the variance between the length, width, and thickness of each seed, with each of these numbers being divided by the highest value in each category; the values would then vary between 0 and 1 . SS values near zero represent spherically shaped forms, while values near one represent seeds that are elongated, cylindrical, or flattened. Only the anatomical parts belonging to the seed itself were considered in these calculations, disregarding structures belonging to the fruit, except in cases where it were inseparable. Included in these measurements were the tegument, embryo, and endosperm; dispersal structures were not considered. Five individuals per species were selected; the seeds of herbarium specimens were measured for those species not fruiting during the sampling period.

Based on the surveys undertaken in 2005 and 2011, it was calculated recruitment (individuals that surpassed the inclusion parameters), mortality, and the basal area growth of the species. Annual mortality rates (MR) were calculated following Lieberman \& Lieberman (1987); basal area growth rates (BAG) were obtained using a mathematical deduction of the equations of Sheil \& May (1996). Basal area growth and mortality are the demographic rates.

\section{Statistical analyses}

Data analyses were performed using Microsoft Excel 2007 Windows version 7 and SPSS version 13 (2004). Pearson correlations were used to evaluate interspecific relationships between the average values of the traits considered and demographic rates of the species, and multiple regressions were subsequently applied to identify to what degree the traits determined the observed variations in those rates. The normalities of the variables traits and demographic rates were examined using the Kolmogorov-Smirnov test, and data showing normal distributions were analyzed using Pearson's correlation. Mortality rates that did not demonstrate normal distributions were log transformed (Martínez-Vilalta et al., 2010) before analysis using Pearson's correlation, considering significance levels of 0.05 and 0.01 (Poorter et al., 2008).

Factorial analysis was performed using the coefficient of linear correlation as a measure of the association between each pair of variables in order to reduce the original set of variables, and therefore the dimensionality of the data, into smaller numbers of linear combinations. It would explain the greatest part of the variability in the original data and increase the correlation structure. To that end, principal component analysis was used for extracting the factorial charges (Mingoti, 2005). The choice of the number of factors in the analyses represented approximately $70 \%$ of the cumulative variance. The interpretation of the factors, regarding simplifying the data structure, was employed varimax type orthogonal rotation of the coordinate axes. The factorial scores were obtained using regression, considering a linear combination of the factors that underwent rotation and standardized measurements (Manly, 1997).

The most important components of the variance were detected based on the scores established by the factorial analyses, and a grouping analysis hierarchy has been created to separate or classify the species into mutually exclusive groups so that the subgroups formed would demonstrate high internal similarities and large external differences (Moori et al., 2002). 
Ward's method was used to delimit the groups and their respective Euclidian distances. Discriminant analysis was used to verify the pertinence of the groups formed through grouping analysis, using Fisher's discriminant function, as determined according to Hair et al. (2009).

\section{Results}

In 2011, 86 woody species were found in the Mata de Zambana forest fragment, and 47 were selected for further analysis, considering the measurable mortality and growth rates - necessary for correlation with the traits, allowing the analyses proposed in the present work. These 47 species were responsible for $92 \%$ of the basal area determined in 2011.
SLA varied from 57.69 to $240.25 \mathrm{~cm}^{2}$.g-1; BWD oscillated between 0.256 and 0.843 g.cm-3; maximum height ranged from 1.6 and $23.82 \mathrm{~m}$; SS ranged from 0.0088 and 0.2812 . From 14 specific correlations analyzed, three (BWD $\mathrm{x}$ SLA, BAG x SS, and BAG x MR) demonstrated significant values, with $\mathrm{r}=-0.30 ; 0.25$ and -0.29 respectively (Table 1); the correlation MR $\mathrm{x}$ Hmax was highly significant, $r=-0.38$ (Table 1 ). Among the negative correlations (although not significant) were BWD x SLA, BWD X SS, BWD $\mathrm{x}$ MR, Hmax x MR, and BAG x MR, which all followed the initial predictions, having r-values above 0.20 .

Table 1. Pearson Correlation Coefficients between traits [specific leaf area (SLA), wood density (BWD), maximum height (Hmax) and seed shape (SS)] and demographic rates [mortality rate (MR) and growth rate (BAG)] in the canopy and sub-canopy of the Mata de Zambana forest at Igarassu, Pernambuco State, Brazil. Level of significance: $* P<0.05$; $* * P<0.01$; n.s. $P>0.05$.

\begin{tabular}{|c|c|c|c|c|c|c|c|c|c|c|c|c|}
\hline \multirow{2}{*}{ Variables } & \multicolumn{2}{|c|}{ BWD } & \multicolumn{2}{|c|}{ Hmax } & \multicolumn{2}{|l|}{ SLA } & \multicolumn{2}{|l|}{ SS } & \multicolumn{2}{|l|}{ MR } & \multicolumn{2}{|l|}{ BAG } \\
\hline & $\mathbf{R}$ & $P$ & $\mathbf{R}$ & $P$ & $\mathbf{R}$ & $P$ & $\mathbf{R}$ & $P$ & $\mathbf{r}$ & $P$ & $\mathbf{R}$ & $P$ \\
\hline BWD & 1.00 & - & -0.02 & n.s & -0.30 & $*$ & -0.24 & n.s & -0.22 & n.s & 0.13 & n.s \\
\hline Hmax & & & 1.00 & - & 0.04 & n.s & 0.10 & n.s & -0.38 & $* *$ & 0.14 & n.s \\
\hline SLA & & & & & 1.00 & - & 0.14 & n.s & 0.15 & n.s & -0.15 & n.s \\
\hline SS & & & & & & & 1.00 & - & -0.15 & n.s & 0.25 & $*$ \\
\hline MR & & & & & & & & & 1.00 & - & -0.29 & $*$ \\
\hline BAG & & & & & & & & & & & 1.00 & - \\
\hline
\end{tabular}

Individual analyses of each characteristic and rate indicated that basic wood density and Hmax explained $49 \%$ and $15 \%$ of the variation in MR respectively; SLA and SS were responsible for only $2 \%$ each. When the influences of all the traits were considered, the model explained $34 \%$ of the variation. The co-linearity of the data and the lack of homoscedasticity between them influenced the low coefficient of the determination. BWD was found to be a significant predictor of MR in the regression analyses (Table 2).

Table 2. Multiple regression analysis of traits [specific leaf area (SLA), wood density (BWD), maximum height (Hmax) and seed shape (SS)] and demographic rates [mortality rate (MR) and growth rate (BAG)] in the canopy and sub-canopy of the Mata de Zambana forest at Igarassu, Pernambuco State, Brazil. Level of significance: $* P<0.05 ; * * P<0.01$; n.s $P>0.05$.

\begin{tabular}{lllllll}
\hline Variables & MR & & \multicolumn{3}{c}{ BWD } & \\
& $\boldsymbol{B}$ & $\mathbf{r}^{\mathbf{2}}$ & $\boldsymbol{P}$ & $\boldsymbol{B}$ & $\mathbf{r}^{\mathbf{2}}$ & $\boldsymbol{P}$ \\
\hline BWD & -0.22 & 0.49 & $* *$ & 0.13 & 0.02 & $* *$ \\
Hmax & -0.38 & 0.15 & $* *$ & 0.14 & 0.02 & $* *$ \\
SLA & 0.15 & 0.02 & n.s & -0.15 & 0.02 & $* *$ \\
SS & -0.15 & 0.02 & Ns & 0.25 & 0.06 & $*$ \\
\hline Multiple model & & $\mathbf{0 . 3 4}$ & $* *$ & & $\mathbf{0 . 2 0}$ & $* *$ \\
\hline
\end{tabular}

The influence of growth rate traits was found to be low when observed by multiple regression analysis. The traits BWD, Hmax, SLA, and SS, when individually analyzed, influenced 
$2 \%, 2 \%, 2 \%$ and $6 \%$ of the BAG respectively. When the influence of those traits was superimposed on basal area growth rates (BAG), the model explained only $20 \%\left(\mathrm{r}^{2}=0.20\right)$ of the variation in BAG (Table 2). The co-linearity and absence of homoscedasticity in the data did not allow us to conclude whether these traits were good predictors of BAG when examined using regression analysis.

The identification of possible functional groups was performed through factorial analysis of the data, which detected the factorial charges of each variable through the orthogonal varimax rotation. The adjusted factorial model was validated, as $70.44 \%$ of the total variability was explained by the three factors composed of traits and rates (Table 3). It could be seen that the variables MR and Hmax were more optimally rotated using the varimax method, with $26.98 \%$ of the variance being explained by the first factor. The variables SLA and BWD explained $24.73 \%$ of the explicit variance in the second factor. The third factor was composed of the variables BAG and SS, which explained $18.73 \%$ of the observed variation (Table 3).

Table 3. Matrices of factorial charges, communalities and specific variances of the traits and demographic rates obtained by varimax rotation of the canopy and sub-canopy species, in the Mata de Zambana forest at Igarassu, Pernambuco State, Brazil. BWD = basic wood density; Hmax = maximum height; SLA = specific leaf area; $\mathrm{SS}=$ seed shape; $\mathrm{MR}=$ mortality rates; $\mathrm{BAG}=$ growth rates.

\begin{tabular}{|c|c|c|c|c|c|}
\hline \multirow{2}{*}{ Variables } & \multicolumn{3}{|c|}{ Factor } & \multirow{2}{*}{ Communalities } & \multirow{2}{*}{ Specific variance } \\
\hline & 1 & 2 & 3 & & \\
\hline BWD & 0.16 & -0.78 & -0.17 & 0.66 & 0.67 \\
\hline $\operatorname{Hmax}$ & 0.84 & 0.11 & -0.06 & 0.71 & 0.71 \\
\hline SLA & 0.03 & 0.77 & -0.17 & 0.62 & 0.39 \\
\hline SS & 0.29 & 0.40 & 0.66 & 0.68 & 1.12 \\
\hline MR & -0.83 & 0.25 & -0.16 & 0.78 & 1.62 \\
\hline BAG & -0.07 & -0.18 & 0.85 & 0.76 & 1.48 \\
\hline (\%) Variance explained & 26.98 & 24.73 & 18.73 & -- & -- \\
\hline
\end{tabular}

The interpretation of the grouping analysis (Figure 1), whose matrix included the variables MR, BAG, SLA, and Hmax, confirmed the discriminant analysis. The four groups formed by this analysis can be seen in the dendrogram generated by the Ward method (illustrating the Euclidian distances between the groups) (Figure 1), and in the Principal Component Analysis (Figure 2). The groups were: Group 1 - Species with high Hmax and SLA values, low BAG values, and extremely low MR values; Group 2 Species with extremely low Hmax, SLA, and BAG values, associated with high MR rates; Group 3 - Species with low Hmax values and intermediate SLA and MR values, associated with high BAG rates; Group 4 - Species with low SLA and MR values, associated with intermediate Hmax and BAG values (Figure 2, Tables 4 and 5).

Table 4. The pertinence of the classification of the functional groups formed through Discriminant Analysis of the canopy and sub-canopy plants in the Mata de Zambana forest at Igarassu, Pernambuco State, Brazil.

\begin{tabular}{|c|c|c|c|c|c|c|}
\hline & \multirow{2}{*}{ Ward method } & \multicolumn{4}{|c|}{ Prediction of members by group } & \multirow{2}{*}{ Total } \\
\hline \multirow{5}{*}{$\begin{array}{c}\text { Original estimation } \\
(\%)\end{array}$} & & 1 & 2 & 3 & 4 & \\
\hline & 1 & $20(100)$ & 0 & 0 & 0 & $20(100)$ \\
\hline & 2 & 0 & $10(100)$ & 0 & 0 & $10(100)$ \\
\hline & 3 & 0 & 0 & $5(100)$ & 0 & $5(100)$ \\
\hline & 4 & 0 & 0 & 0 & $12(100)$ & $12(100)$ \\
\hline
\end{tabular}


Figure 1. Grouping analysis illustrating the functional similarities between of the of canopy and sub-canopy plants in the Mata de Zambana forest at Igarassu, Pernambuco State, Brazil. The dendrogram, with its respective distances between the groups, was generated by Ward method. The numbers correspond to the species list in SM 1.

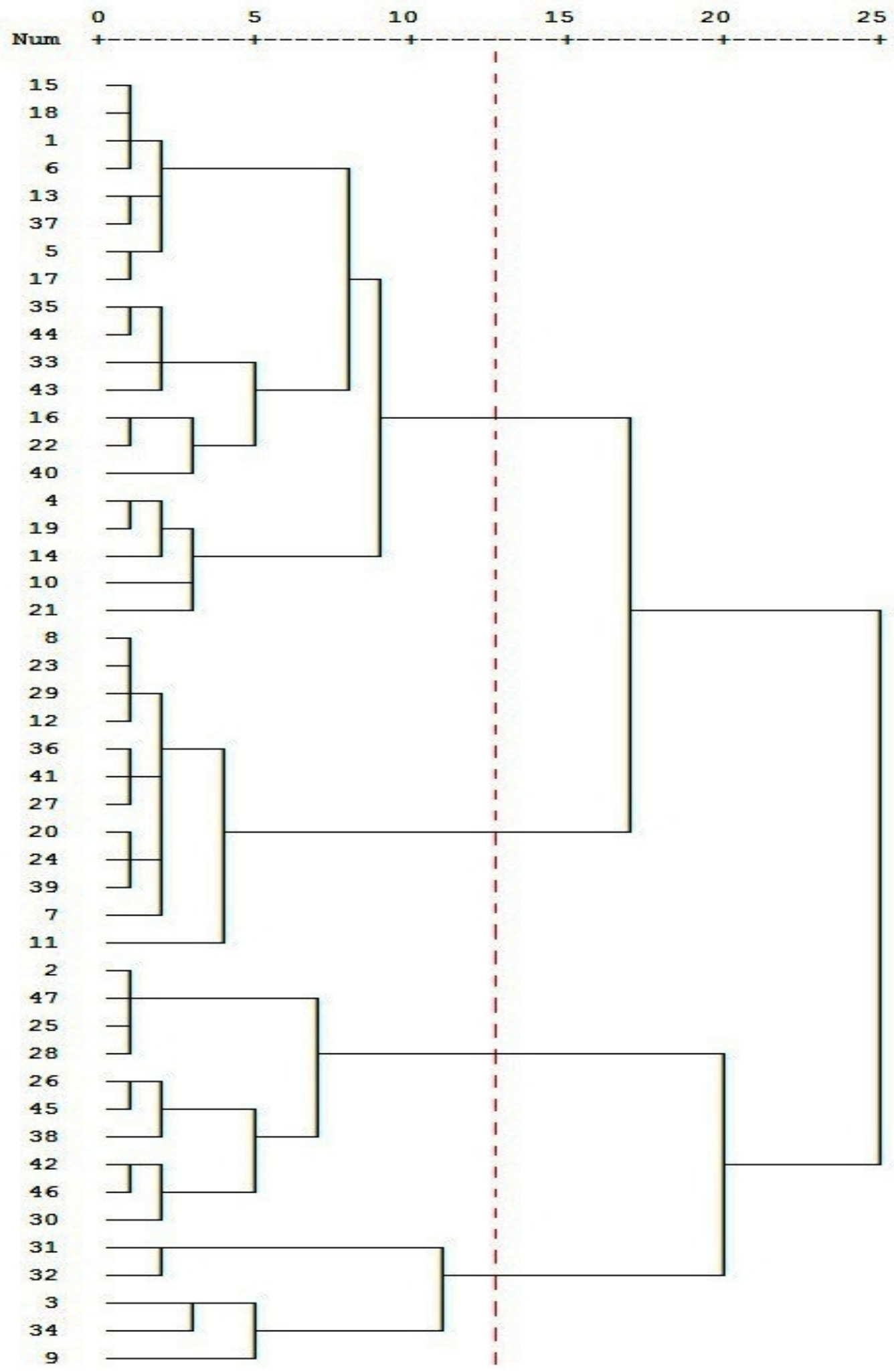

Figure 2. Principal Component Analysis of the canopy and sub-canopy species of the Mata de Zambana forest at Igarassu, Pernambuco State, Brazil. 


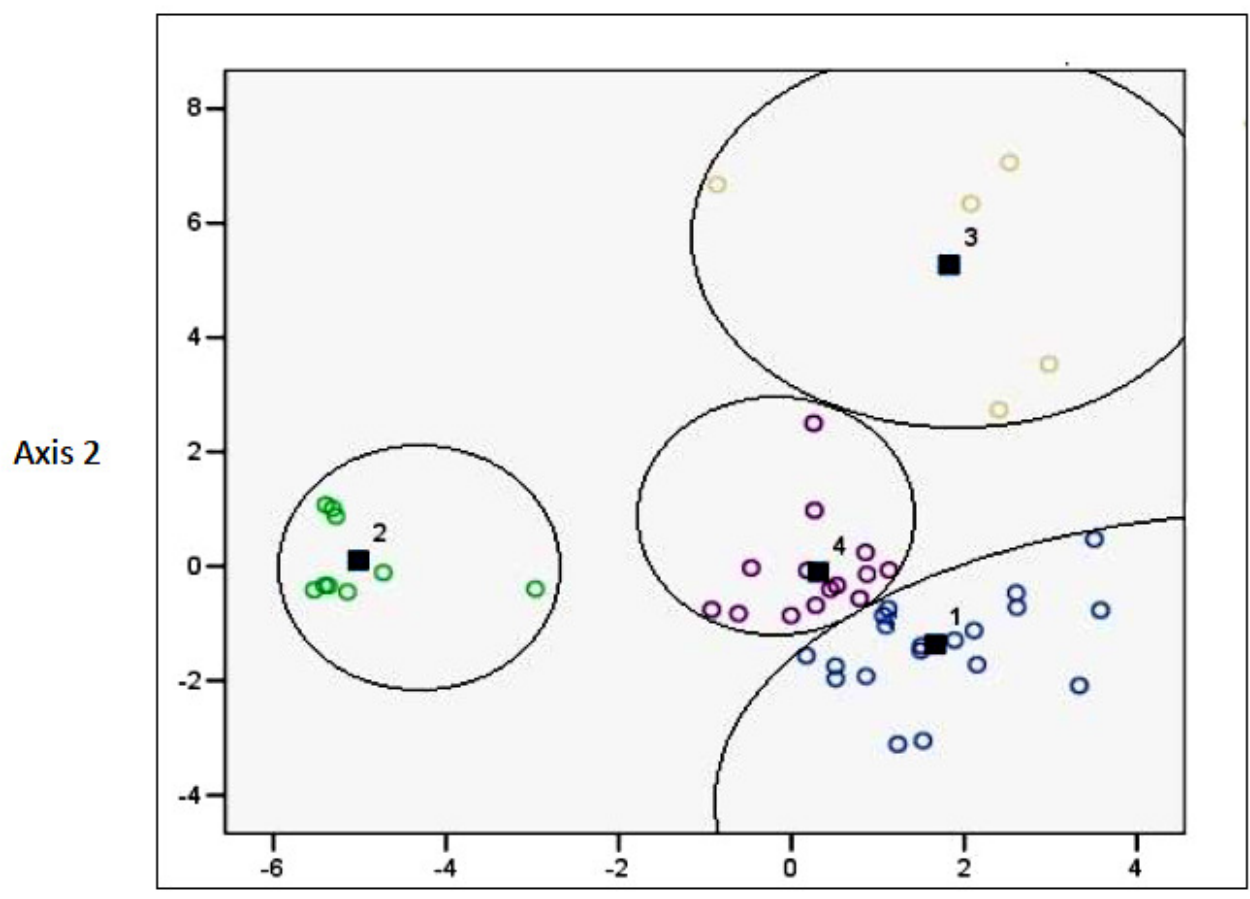

Group

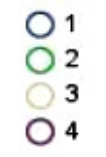

Centroid of the group

Axis 1

Group 1. Species with BWD and SLA values, and extremely low MR values; Group 2. Species with extremely low Hmax, SLA and BWD values, and high MR rates; Group 3. Species with low Hmax values, intermediate SLA and MR values, and high BWD rates; Group 4. Species with SLA and MR values, intermediate Hmax and BWD values. BWD = basic wood density; SLA = specific leaf area; MR = mortality rates; Hmax = maximum height.

Table 5. Discriminate functions of the four functional groups of the canopy and sub-canopy plants in the Mata de Zambana forest at Igarassu, Pernambuco State, Brazil. BWD = basic wood density; Hmax = maximum height; $\mathrm{SLA}=$ specific leaf area; $\mathrm{SS}=$ seed shape; $\mathrm{MR}=$ mortality rates.

\begin{tabular}{lcccc}
\hline \multirow{2}{*}{ Variables } & $\mathbf{1}$ & \multicolumn{4}{c}{ Groups } \\
& $1.11 \mathrm{~h}$ & $0.28 \mathrm{e}$ & $0.47 \mathrm{l}$ & $0.50 \mathrm{~m}$ \\
HMAX & $0.12 \mathrm{~h}$ & $0.02 \mathrm{e}$ & $0.11 \mathrm{~m}$ & $0.07 \mathrm{l}$ \\
SLA & $-45.23 \mathrm{e}$ & $334.60 \mathrm{~h}$ & $6.62 \mathrm{~m}$ & -5.151 \\
MR & $1.85 \mathrm{l}$ & $0.34 \mathrm{e}$ & $9.19 \mathrm{~h}$ & $2.29 \mathrm{~m}$ \\
\hline
\end{tabular}

$\mathrm{h}=$ high value; $\mathrm{m}=$ moderate value; $\mathrm{l}=$ low value; $\mathrm{e}=$ extremely low value.

\section{Discussion}

Most of the correlations between the traits confirmed the expectations, although with low rvalues, with emphasis on the negative correlation between SLA and BWD, as was also indicated by Wright et al. (2007), who reported that leaf size diminished notably with increasing wood density. This relationship may be explained by the sizes and natures of the hydraulic systems of those species, as larger leaves require more sap, a situation rarely observed in plants with dense wood, which conduct sap at lower volumes and velocities (Coomes et al., 2008). It is important to note the negative correlation between BWD and SS, which was unexpected. Few literature have quantified the relationships between SS and other traits, although some studies have noted the existence of a relationship between SS and demographic rates, indicating that decreasing seed shape (greater roundness), with an investment in wood density, resulted in decreasing demographic rates (Thompson et al., 1993; Cornelissen et al., 2003). These results allowed to identify certain important expected trade-offs, such that species that invest in wood density, for example, do not invest in Hmax and reduced SLA.

The significant and negative correlation between mortality rates and growth rates $(r=-$ 0.29 ) indicated that the development of efficient survival strategies, in tandem, optimizes the growth. Variations in these traits result in conflicting demands between growth and survival 
- between the capacities of a species to grow under optimal environmental conditions versus its ability to avoid mortality while exposed to unfavorable conditions (Bazzaz \& Pickett, 1980). Poorter et al. (2008), for example, found nonsignificant correlations with demographic rates in the moist semi-evergreen tropical forest in Bolivia but noted that the difficulties in obtaining precise estimates of MR probably influenced the results.

The unexpected moderate and negative correlation between Hmax and MR observed in Zambana Forest indicates a pattern distinct from that previously reported in the literature. Russo et al. (2010) reported positive correlations between Hmax and MR in forests in New Zealand. Poorter et al. (2008), however, observed negative correlations between these factors in Bolivian and Panamanian moist semi-evergreen tropical forests, perhaps because the successful light energycapturing species become well-established in the canopy and diminishing, thus, the mortality rates, at least for a period. It is possible that the same situation occurred in the Mata de Zambana forest fragment during the study period, with species that successfully invested in Hmax, demonstrating considerably lower mortality rates - suggesting Hmax as a major predictor of MR or that it is an intrinsic characteristic of moist semi-evergreen tropical forests. It can conclude that even if the mortality rate observed in the interval between two surveys does not represent a final pattern; it was certainly influenced by the maximum heights of the species.

A negative correlation between BWD and SLA was expected. The literature indicates that leaves with high SLA values tend to have elevated levels of nitrogen per unit of mass, high water contents, and high rates of both photosynthesis and respiration (Wright et al., 2004; Poorter et al., 2009), therefore demonstrating significant resource expenditures to sustain respiration and transpiration (Cornelissen et al., 2003). Plants with large leaf areas, low dry masses and, consequently, high SLA levels and high nitrogen content, acquire resources and grow rapidly, while plants with contrasting traits conserve their resources more efficiently and persist for longer periods of time (Cornelissen et al., 2003; Poorter et al., 2009). About BWD, various authors have demonstrated a direct relationship between plant survival and growth (Chave et al., 2009; Russo et al., 2010; Speck \& Burgert, 2011). Plants with high percentage of fibrous tissues and thick cell walls have very dense wood (Swenson \& Enquist, 2007), storing more carbon per unit of volume and lower percentage of conductive vessels, which can result in lower photosynthetic and respiration rates
(Weiher et al., 1999), as well as lower rates of biomass accumulation (Poorter et al., 2008; Wright et al., 2010). Survival increases with higher wood density (Poorter et al., 2008; Poorter et al., 2010; Kraft et al., 2010; Martinez-Vilalta et al., 2010; Wright et al., 2010) as dense wood provides greater mechanical stability (Chave et al., 2009) and protection against pathogens, as well as resistance to impacts from other falling trees (Poorter, 2008).

The positive correlation between SS and BAG was expected. Haig \& Westoby (1991) noted that large seeds have larger quantities of reserve materials that increase the probability of successful seedling establishment by allowing longer survival under unfavorable environmental conditions or in localities with low resource availability. Westoby (1998) and Moles et al. (2004) reported that small seeds, normally almost spherical or produced in large numbers, with high dispersal and colonization capacities, had high survival rates. According to Moles et al. (2004), pioneer species and those with rapid growth rates tend to have small spherical seeds. Poorter et al. (2008) reported negative correlations between seed traits (seed mass) and BAG in a forest in Panama and suggested that the small sample size and climatic and edaphic influences skewed their results.

Basic wood density explained $49 \%$ of the regression variation and was the best predictor of MR, presumably because of the energy costs of wood formation, plant architecture, and water conductivity stabilization directly influence species survival (King et al., 2006; Poorter et al., 2008). Hmax explained $15 \%$ of the variation in $\mathrm{MR}$, a result at least partially consistent (it was expected a higher $\mathrm{r}^{2}$ value) with the idea that this particular trait is positively related to mortality rates (Falster \& Westoby, 2005). These results were somewhat similar to those obtained through correlation analyses, where Hmax were the traits most strongly related with MR (although there were outliers in the correlations with Hmax).

Multiple regression analyses were used to estimate which traits was the best predictor of interspecific variations in $\mathrm{BAG}$, although it was not possible to adjust the model to efficiently explain the observed variations in BAG as a function of those traits - the model explained only $20 \%$ of the observed variation. It was expected that growth would be affected by changes in SLA as this traits directly influences biomass investments in light interception (Kitajima, 1994). In the same way, it was expected that BWD would significantly negatively influence BAG, as was reported by Nascimento et al. (2005) in the 
Amazon region, or that SS and Hmax would contribute heavily to the model (negatively and positively, respectively), as was suggested by Cornelissen et al. (2003) and Diaz et al. (2004). It is possible to conclude that the results of the multiple regression analyses did not corroborate the theoretical expectations. It means that the traits examined here were not good predictors of BAG in the Zambana forest. Poorter et al. (2008) suggested that analyses over longer periods of time and with greater numbers of specimens would probably be necessary. It thus appears that increases in BAG were influenced by unassociated traits and factors, such as fragment size, as well as climatic and edaphic influences (Laurance et al., 1998; Harper et al., 2005; Poorter et al., 2008).

Factorial analysis of the data indicated that three factors were critical to the behavior of the traits and mortality rates by the factorial charges. Hmax and MR took positions as the first most important factors, in opposite directions, indicating that mortality regressed as the species invested in Hmax during the interval between the two surveys. This strategy benefited species that invested in Hmax because, in their competition for light resources, those plants that successfully grew towards the upper canopy became wellestablished (Westoby et al., 2002). It is possible that this same situation occurred in the Mata de Zambana forest fragment during the study period, with species that successfully invested in Hmax demonstrating considerably lower mortality rates - suggesting Hmax as a major predictor of MR. It was possible to conclude that even if the mortality rate observed in the interval between the two surveys does not represent a final pattern, it was certainly influenced by the maximum heights of the species. However, Westoby et al. (2002) noted that tree heights could vary in different climatic zones and among the various sites within landscapes.

BWD and SLA took up positions as the second most important factors, although in opposite directions, so that species that invested in BWD showed small investments in SLA, demonstrating a trade-off between growth and survival (Westoby, 1998). Contrary to the expectations, SS and BAG were positioned as third tier factors with positive values. It had expected, supported by the observations of Westoby (1998), that species with spherical seeds would be better colonizers and would also demonstrate accelerated growth rates.

The similarities between the species regarding their traits (SLA and Hmax) and demographic rates (MR and $\mathrm{BAG}$ ) allowed the separation into groups showing four functional strategies related to the growth, reproduction, and survival, and demonstrating, once again, the acceptance of important trade-offs, corroborating the literature.

Group 1 comprises 20 species, demonstrating greater investments in SLA and Hmax, that adopted the strategy of reacting to rapid growth opportunities, as noted by Reich et al. (1999), and demonstrated reduced mortality rates during the present study (2005 - 2011) - a strategy predicted by King et al. (2006). The elevation of SLA and Hmax were predictable, and it was clear that investment in Hmax was the determining factor for the formation of this group. Although the correlation between Hmax and mortality was contrary to the theoretical expectations, it emphasizes that the species had become better established as they invested more in Hmax during the study period. Group 2 comprises 10 species with the smallest Hmax, SLA and BWD values, and the highest mortality rates. Some of the species of this group had few individuals were understory plants. It was not possible, therefore, to describe accurately the strategies adopted by this group as the small numbers of individuals result in statistical inaccuracies that over - or under-estimate their dynamics. These species did not, however, make large investments in any of the traits evaluated, having reduced basal area growth rates and high mortality rates - which leads to believe that other species constantly substitute them, and adaptive strategy in itself, according to Lavorel et al. (1997). Group 3 comprises five species that display a strategy quite distinct from others: low Hmax values, moderate SLA values, and intermediate MR rates, but with high basal area growth rates. This strategy is probably controlled by other traits than those examined here or reflects random occurrences, and it was not possible to clearly define their functional strategies. Group 4 comprised 12 species and had its centroid near Group 1, indicating that the species showed similar strategies but were discriminated in the Grouping Analysis by demonstrating low SLA values, an only moderate growth regarding diameter and height gains, and low mortality rates. Reich et al. (1999) likewise identified this group and deduced that their low SLA values were related to reduced capacity to react to rapid growth opportunities - it is consistent with low investments in Hmax and BWD; according to Poorter et al. (2008), low SLA and Hmax indices would naturally be associated with low mortality rates. 


\section{Conclusion}

Considering that some of the correlations found diverged from previously published results (such as the negative relationship between maximum height and mortality) it may reflect regional climatic seasonality or indicate that this strategy benefits plant species that reach the upper canopy and thus become well established.

\section{Acknowledgements}

HAM and MJNR were supported by grants from the Conselho Nacional de Desenvolvimento Científico e Tecnológico. This paper was conducted as part of the Mestrado em Ciências Florestais, at the Universidade Federal Rural de Pernambuco, Brazil.

\section{References}

BAZZAZ, F. A.; PICKETT, S. T. A. 1980. Physiological ecology of tropical succession: a comparative review. Annu. Rev. Ecol. Syst., v.11, p.287-310.

ACKERLY, D. D. 2003. Community assembly, niche conservatism, and adaptive evolution in changing environments. Int. J. Plant Sci., v.16. p.165-184.

CHATURVEDI, R. K.; RAGHUBANSHI, A. S.; SINGH, J. S. 2011. Leaf attributes and tree growth in a tropical dry forest. J. Veg. Sci., v.22, p.917-931.

CHAVE, J.; COOMES, D.; JANSEN, S.; LEWIS, S. L.; SWENSON, N. G.; ZANNE, A. E. 2009. Towards a worldwide wood economics spectrum. Ecol. Lett., v.12, p.351-366.

CHAVE， J.; MULLER-LANDAU, H. C.; BAKER, T. R.; EASDALE, T. A.; STEEGE, H. T.; WEBB, C. O. 2006. Regional and phylogenetic variation of wood density across 2,456 Neotropical tree species. Ecol. Appl., v.16, p.356-367.

COHEN, J.; COHEN, P.; WEST, S. G.; AIKEN, L. S. 2013. Applied multiple regression/correlation analysis for the behavioral sciences. Routledge, New Jersey.

COOMES, D. A.; HEATHCOTE, S.; GODFREY, E. R.; SHEPHERD, J. J.; SACK, L. 2008. Scaling of xylem vessels and veins within the leaves of oak species. Biol. Letters, v.4, p.302-306.

CORNELISSEN, J. H. C.; LAVOREL, S.; GARNIER, E.; DIAZ, S.; BUCHMANN, N.;
GURVICH, D. E.; REICH, P. B.; TER STEEGE, H.; MORGAN, H. D.; VAN DER HEIJDEN, M. G. A. 2003. A handbook of protocols for standardized and easy measurement of plant functional traits worldwide. Aust. J. Bot., v.51, p.335-380.

CPRH (Companhia Pernambucana do Meio Ambiente). 2003 Diagnóstico socioambiental do litoral norte de Pernambuco. CPRH, Recife.

DIAZ, S.; HODGSON, J. G.; THOMPSON, K.; CABIDO, M.; CORNELISSEN, J. H. C.; JALILI, A.; MONTSERRAT-MARTI, G.; GRIME, J. P.; ZARRINKAMAR, F.; ASRI, Y.; BAND, S. R.; BASCONCELO S, CASTRO-DIEZ, P.; FUNES, G.; HAMZEHEE, B.; KHOSHNEVI. M, PEREZHARGUINDEGUY, N.; PEREZ-RONTOME, M. C.; SHIRVANY, F. A.; VENDRAMINI, F.; YAZDANI, S.; ABBAS-AZIMI, R.; BOGAARD, A.; BOUSTANI, S.; CHARLES, M.; DEHGHAN, M.; DE TORRES-ESPUNY, L.; FALCZUK, V.; GUERRERO-CAMPO, J.; HYND, A.; JONES, G.; KOWSARY, E.; KAZEMI-SAEED, F.; MAESTRO-MARTINEZ, M.; ROMO-DIEZ, A.; SHAW, S.; SIAVASH, B.; VILLAR-SALVADOR, P.; ZAK, M. R. 2004. The plant traits that drive ecosystems: Evidence from three continents. J. Veg. Sci., v.15, p.295304.

DIAZ, S.; LAVOREL, S.; DE BELLO, F.; QUÉTIER, F.; GRIGULIS, K.; ROBSON, T. M. 2007. Incorporating plant functional diversity effects in ecosystem service assessments. PNASBiology, v.104, p.20684-20689.

FALSTER, D. S.; WESTOBY, M. 2003. Plant height and evolutionary games. Trends Ecol. Evol., v.18, p.337-343.

HAIG, D.; WESTOBY, M. 1991. Seed size, pollination costs and angiosperm success. Ecol. Evol, v.5, p.231-247.

HAIR JUNIOR, J. F.; ANDERSON, R. E.; TATHAM, R. L.; BLACK, W. C. 2009. Análise Multivariada de Dados. Tradução Adonai Schlup

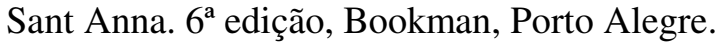

HARPER, K. A.; MACDONALD, S. E.; BURTON, P. J.; CHEN, J.; BROSOFSKE, K. D. 2005. Edge influence on forest structure and composition in fragmented landscapes. Conserv. Biol., v.19, p.768-782. 
HOOPER, D. U.; VITOUSEK, P. M. 1997. The effects of plant composition and diversity on ecosystem processes. Science, v.277, p.13021305.

KING, D. A.; DAVIES, S. J.; TAN, S.; SUPARDI, M. N. N. 2006. The role of wood density and stem support costs in the growth and mortality of tropical trees. J. Ecol., v.94, p.670680.

KITAJIMA, K. 1994. Relative importance of photosynthetic traits and allocation patterns as correlates of seedling shade tolerance of 13 tropical trees. Oecologia, v.98, p.419-428.

KRAFT, N. J. B.; ACKERLY, D. D. 2010. Functional trait and phylogenetic tests of community assembly across spatial scales in an Amazonian forest. Ecol. Monogr., v.80, p.401422.

LAURANCE, W. F.; FERREIRA, L. V.; RANKIN-DE-MERONA, J. M.; LAURANCE, S. G.; HUTCHINGS, R.; LOVEJOY, T. 1998. Effects of forest fragmentation on recruitment patterns in Amazonian tree communities. Conserv. Biol., v.12, p.460-464.

LAVOREL, S.; MCINTYRE, S.; LANDSBERG, J.; FORBES, T. D. A. 1997. Plant functional classifications: from general groups to specific groups based on response to disturbance. Trends Ecol. Evol., v.12, n.474-478.

LIEBERMAN, D.; LIEBERMAN, M. 1987. Forest tree growth and dynamics at La Selva, Costa Rica (1969-1982). J. Trop. Ecol., v.3, p.347-358.

LINS-E-SILVA, A. C. B. 2010. Influência da área e da heterogeneidade de habitats na diversidade vegetal em fragmentos de Floresta Atlântica. Tese de Doutorado, Universidade Federal do Rio de Janeiro, Rio de Janeiro, Brasil.

MANLY, B. F. J. 1997. Multivariate statistical methods: a primer. 2. ed. Chapman \& Hall, London.

MARTINEZ-VILALTA, J.; MENCUCCINI, M.; VAYREDA, J.; RETANA, J. 2010. Interspecific variation in functional traits, not climatic differences among species ranges, determines demographic rates across 44 temperate and Mediterranean tree species. J. Ecol., v.98, p.14621475.
MELO, F. P. L.; ARROYO-RODRÍGUEZ, V.; FAHRIG L.; MARTÍNEZ-RAMOS, M.; TABARELLI, M. 2013. On the hope for biodiversity-friendly tropical landscapes. Trends Ecol. Evol., v.28, p.462-468.

MINGOTI, A. S. 2005. Análise de dados através de métodos de estatística multivariada: uma abordagem aplicada. UFMG, Belo Horizonte.

MOLES, A. T.; FALSTER, D. S.; LEISHMAN, M. R.; WESTOBY, M. 2004. Small-seeded species produce more seeds per square meter of canopy per year, but not per individual per lifetime. J. Ecol., v.92, p.384-396.

MOORI, R. G.; MARCONDES, R. C.; ÁVILA, R. T. A. 2002. Análise de agrupamentos como instrumento de apoio à melhoria da qualidade dos serviços aos clientes. Rev. Adm. Conte, v.6, p.6384.

MULLER-LANDAU, H. C. 2004. Interspecific and inter-site variation in wood specific gravity of tropical trees. Biotropica, v.36, p.20-32.

NASCIMENTO, H. E. M.; LAURANCE, W. F.; CONDIT, R.; LAURANCE, S. G.; ANGELO, S. 2005. Demographic and life-history correlates for Amazonian trees. J. Trop. Ecol., v.16, p.625-634.

POORTER, L. 2008. The relationships of wood-, gas- and water fractions of tree stems to performance and life history variation in tropical trees. Ann. Bot., v.102, p.367-375.

POORTER, L.; BONGERS L.; BONGERS F. 2006. Architecture of 54 moist forest tree species: traits, trade-offs, and functional groups. Ecology, v.87, p.1289-1301.

POORTER, L.; MCDONALD, I.; ALARCO,; A.; FICHTLER, E.; LICONA; J.C.; PENA-CLAROS, M.; STERCK, F.; VILLEGAS, Z.; SASSKLAASSEN, U. 2010. The importance of wood traits and hydraulic conductance for the performance and life history strategies of 42 rainforest tree species. New Phytol., v.85, p.481492.

POORTER, L.; WRIGHT, S.J.; PAZ, H.; ACKERLY, D. D.; CONDIT, R.; IBARRAMANRIQUEZ, G.; HARMS, K. E.; LICONA; J. C.; MARTINEZ-RAMOS, M.; MAZER, S. J.; MULLER-LANDAU, H. C.; PENA-CLAROS, M.; WEBB, C. O.; WRIGHT, I. J. 2008. Are functional traits good predictors of demographic 
rates? Evidence from five Neotropical forests. Ecology, v.89, p.908-920.

POORTER, H.; NIINEMETS, U.; POORTER, L.; WRIGHT, I. J.; VILLAR, R. 2009. Causes and consequences of variation in leaf mass per area (LMA): a meta-analysis. New Phyt., v.182, p.565588.

REICH, P. B.; ELLSWORTH, D. S.; WALTERS, M. B.; VOSE, J. M.; GRESHAM, C.; VOLIN, J. C.; BOWMAN, W. D. 1999. Generality of leaf trait relationships: a test across six biomes. Ecology, v.80, p.1955-1969.

REICH, P. B.; WRIGHT, I.J.; CAVENDERBARES, J.; CRAINE, M. J.; OLEKSYN, J.; WESTOBY, M.; WALTERS, M. B. 2003. The evolution of plant functional variation: traits, spectra, and strategies. Int. J. Plant Sci., v.164, n.3 Suppl., p.S143-S164.

RUSSO, S. E.; JENKINS, K. L.; WISER, S. K.; URIARTE, M.; DUNCAN, R. P.; COOMES, D. A. 2010. Interspecific relationships among growth, mortality and xylem traits of woody species from New Zealand. Funct. Ecol., v.24, p.253-262.

SACK, L.; FROLE, K. 2006. Leaf structural diversity is related to hydraulic capacity in tropical rain forest trees. Ecology, v.87, p.483491.

SCHESSL, M.; SILVA, W. L.; GOTTSBERGER, G. 2008. Effects of fragmentation on forest structure and litter dynamics in Atlantic rainforest in Pernambuco, Brazil. Flora, v.203, p.215-228.

SCHWINNING, S.; WEINER, J. 1998. Mechanisms determining the degree of size asymmetry in competition among plants. Oecologia, v.113, p.447-455.

SHEIL, D.; MAY, R.M. 1996. Mortality and recruitment rate evaluations in heterogeneous tropical forests. J. Ecol., v.84, p.91-100.

SPECK, T.; BURGERT I. 2011. Plant Stems: functional design and mechanics. Annu. Rev. Mater. Res., v.41, p.169-193.

SPSS (Statistical Package for the Social Sciences). 2004. Command Syntax Reference. SPSS ${ }^{\circledR} 13.0$, Chicago.
SWENSON, N. G.; ENQUIST, B. J. 2007. Ecological and evolutionary determinants of a key plant functional trait: wood density and its community-wide variation across latitude and elevation. Am. J. Bot., v.94, p.451-459.

THOMPSON, K.; BAND, S. R.; HODGSON, J. G. 1993. Seed size and shape predict persistence in soil. Funct. Ecol., v.7, p.236-241.

TRINDADE, M. B.; LINS-E-SILVA, A. C. B.; SILVA, H. P.; FIGUEIRA, S. B.; SCHESSL, M. 2008. Fragmentation of the Atlantic rainforest in the northern coastal region of Pernambuco, Brazil: recent changes and implications for conservation. Bioremed, Biod. Bioav., v.2, p.5-13.

WEIHER, E.; VAN DE WERF, A.; THOMPSON, K.; RODERICK, M.; GARNIER, E.; ERIKSSON, O. 1999. Challenging Theophrastus: a common core list of plant traits for functional ecology. J. Veg. Sci., v.10, p.609620.

WESTOBY, M. 1998. A leaf-height-seed (LHS) plant ecology strategy scheme. Plant Soil, v.199, p.213-227.

WESTOBY, M.; FALSTER, D. S.; MOLES, A. T. VESK, P. A.; WRIGHT, I. J. 2002. Plant ecological strategies: some leading dimensions of variation between species. Ann. Rev. Ecol. Syst., v.33, p.125-159.

WESTOBY, M.; WRIGHT, I. J. 2006. Land-plant ecology on the basis of functional traits. Trends Ecol. Evol., v.21, p.261-268.

WRIGHT, I. J.; ACKERLY, D. D.; BONGERS, F.; HARMS, K. E.; IBARRA-MANRÍQUEZ, G.; MARTÍNEZ-RAMOS, M.; MAZER, S.J.; MULLER-LANDAU, H. C.; PAZ, H.; PITMAN, N. C. A.; POORTER, L.; SILMAN, M.; VRIESENDORP, C. F.; WEBB, C. O.; WESTOBY, M.; WRIGHT, S. J. 2007. Relationships among ecologically important dimensions of plant trait variation in seven Neotropical Forests. Ann. Bot., v.99, p.10031015.

WRIGHT, I. J.; CANNON, K. 2001. Relationships between leaf lifespan and structural defenses in a low nutrient, sclerophyll flora. Funct. Ecol., v.15, p.351-359.

WRIGHT, S. J.; KITAJIMA, K.; KRAFT, N.; REICH, P.; WRIGHT, I. 2010. Functional traits 
Journal of Environmental Analysis and Progress V. 02 N. 01 (2017) 23-35

and the growth-mortality tradeoff in tropical trees. Ecology, v.91, p.3664-3674.

WRIGHT, S. J.; MULLER-LANDAU, H.; CONDIT, C. R.; HUBBELL, S. P. 2003. Gapdependent recruitment, realized vital rates, and size distributions of tropical trees. Ecology, v.84, p.3174-3185.

WRIGHT, I. J.; REICH, P. B.; WESTOBY, M.; ACKERLY, D. D.; BARUCH, Z.; BONGERS, F.; CAVENDER-BARES, J.; CHAPIN, T.;
CORNELISSEN, J. H. C.; DIEMER, M.; FLEXAS, J.; GARNIER, E.; GROOM, P. K.; GULIAS, J.; HIKOSAKA, K.; LAMONT, K. B.; LEE, T.; LEE, W.; LUSK, C.; MIDGLEY, J. J.; NAVAS, M.; NIINEMETS, U.; OLEKSYN, J.; OSADA, N.; POORTER, H.; POOT, P.; LYNDA, P.; PYANKOV, V. I.; ROUMET, C.; SEAN, C.; THOMAS, S. C.; MARK, G.; TJOELKER, M. G.; VENEKLAAS, E. J.; VILLAR, R. 2004. The worldwide leaf economics spectrum. Nature, v.428, p.821-827. 